\title{
МЕХАНІЗМ УПРАВЛІННЯ КОНКУРЕНТОСПРОМОЖНІСТЮ УНІВЕРСИТЕТУ НА РИНКУ ОСВІТНІХ ПОСЛУГ
}

\section{MECHANISM OF UNIVERSITY COMPETITIVENESS MANAGEMENT IN THE MARKET OF EDUCATIONAL SERVICES}

\author{
Кобідзе Нонна Нодарівна \\ аспірант, \\ Донецький національний університет імені Василя Стуса \\ ORCID: https://orcid.org/0000-0002-5493-2263 \\ Kobidze Nonna \\ Vasyl' Stus Donetsk National University
}

\begin{abstract}
У статті досліджено проблему управління конкурентоспроможністю університету, визначено можливі напрями ії̈ підвищення та розроблено механізм управління конкурентоспроможністю університету на ринку освітніх послуг. Визначено, що механізм управління конкурентоспроможністю університету повинен включати в себе наступні структурні елементи: цілі управління, фрактори управління, організаційну структуру управління, ресурси управління, методи впливу на ффактори (напрями, інструменти) та результати управління. Використання механізму дозволяє визначити рівень конкуренції на ринку освітніх послуг, провести аналіз впливу внутрішніх та зовнішніх чинників на рівень конкурентоспроможності університету, виявити основні напрямки підвищення рівня його конкурентоспроможності, оцінити ефективність запропонованих заходів.
\end{abstract}

Ключові слова: конкурентоспроможність, університет, ринок освітніх послуг, управління конкурентоспроможністю, механізм управління, процес управління, інструменти управління.

В статье исследована проблема управления конкурентоспособностью университета, определены возможные направления ее повышения и разработан механизм управления конкурентоспособностью университета на рынке образовательных услуг. Определено, что механизм управления конкурентоспособностью университета должен включать в себя следующие структурные элементы: цели управления, сракторы управления, организационную структуру управления, ресурсы управления, методы воздействия на фракторы (направления, инструменты) и результаты управления. Использование механизма позволяет определить уровень конкуренции на рынке образовательных услуг, провести анализ влияния внутренних и внешних факторов на уровень конкурентоспособности университета, выявить основные направления повышения уровня его конкурентоспособности, оценить эффрективность предложенных мероприятий.

Ключевые слова: конкурентоспособность, университет, рынок образовательных услуг, управление конкурентоспособностью, механизм управления, процесс управления, инструменты управления.

The article investigates the problem of managing the competitiveness of the university, identifies possible directions for its improvement and develops a mechanism for managing the competitiveness of the university in the market of educational services. It is established that at the present stage of higher education development it is expedient to formulate a comprehensive approach to the formation of university competitiveness, which includes the following areas: improving the basic relations of the university with internal and external environments, using modern principles and improving methods market of educational services. It is determined that the mechanism of managing the competitiveness of the university should include the following structural elements: management goals, management factors, organizational management structure, management resources, methods of influencing factors (directions, tools) and management results. The formation of the mechanism of competitiveness management should be based on a set of principles of systematization, target orientation, taking into account the specifics of activities, information support, use of modern technologies and tools, comprehensive assessment of factors. The proposed mechanism allows to form long-term and sustainable competitive advantages based on the use of various methods and tools, which will result in an improvement of the university's competitive position in the market of educational services. The use of the mechanism allows to determine the level of competition in the market of educational services, to analyze the impact of internal and external factors on the level of competitiveness of the university, to identify the 
main directions of increasing its competitiveness, to assess the effectiveness of proposed measures. It is proved that a comprehensive approach to managing the competitiveness of the university in a market environment will promote the development of a competitive strategy for its development, which will include educational, business, entrepreneurial and educational activities that meet the general principles of management and principles of forming and maintaining university competitiveness.

Keywords: competitiveness, university, market of educational services, competitiveness management, management mechanism, management process, management tools.

Постановка проблеми. Сучасний етап розвитку вищої освіти України характеризується посиленням конкурентної боротьби на ринку освітніх послуг. Така ситуація зумовлена суттєвим збільшенням чисельності закладів вищої освіти, скороченням чисельності абітурієнтів, зростанням можливостей отримання освіти за кордоном, підвищенням вимог роботодавців до випускників закладів вищої освіти. У сучасному світі вища освіта стає однією зі сорер, де активно фрормуються нові підходи до управління діяльністю, націлені на підвищення соціально-економічної ефрективності та динамічний розвиток. Процеси управління в закладах вищої освіти набувають рис підприємницького змісту. Відчутний ринковий вплив, напружена конкуренція та невизначені перспективи актуалізують питання конкурентоспроможності університетів. Відсутність оперативних рішень обумовлена комплексом чинників, що визначають суперечливу комбінацію ринкових та неринкових задач університету, усвідомлення яких та імплементація на цій основі релевантних інструментів реагування потребують нового рівня менеджменту. Критично важливі пріоритети нових підходів охоплюють складне коло задач: забезпечення органічного та продуктивного поєднання високої суспільної місії 3 гострими потребами поточної рентабельності, академічних традицій та свободи з регламентацією та обмеженнями бюджету, срормальних систем забезпечення якості з щирим усвідомленням змісту цієї діяльності. Додає складності потреба врахування впливу та очікувань кожного представника динамічної полісуб'єктної системи споживачів освітніх послуг університету (держава, бізнес, студенти та майбутні студенти, домогосподарства, роботодавці, поточні та перспективні ринкові очікування щодо якості фрахівців) послуг університету, вплив та очікування кожного з яких мають бути враховані. Отже, визначення ефективних способів підвищення конкурентоспроможності університету є вкрай актуальним та потребує більш глибокого та детального дослідження.

Аналіз останніх досліджень і публікацій. Значний внесок у дослідження питань фрормування та розвитку конкурентоспроможності закладів вищої освіти зробили як зарубіжні, так і вітчизняні вчені, серед яких: Л. Антонюк [1], 3. Домбровський, В. Заболотний, І. Іванова, І. Каленюк [2], Л. Карамушка, Б. Корольова, О. Кратт, О. Левченко [3], І. Лошенюк, С. Мамонтов, Т. Нагорняк [4; 5], М. Ніязова, Т. Оболенська, Ю. Петруня, Т. Решетілова, А. Тибіня, Н. Ушакова, Є. Хриков, Л. Шаульська $[5 ; 6]$ та інші.

Виділення невирішених раніше частин загальної проблеми. Сьогодні проблема вивчення конкурентоспроможності університету залишається актуальною та потребує доопрацювання існуючого та розробки нового набору дієвих інструментів та методів, що забезпечать побудову ефективного механізму управління конкурентоспроможністю університету на ринку освітніх послуг.

Формулювання цілей статті (постановка завдання). Метою статті $є$ дослідження проблем управління конкурентоспроможністю університету, визначення можливих напрямів ії підвищення та розробка механізму управління конкурентоспроможністю університету на ринку освітніх послуг.

Виклад основного матеріалу дослідження. Структурні зрушення на ринку освітніх послуг обумовлюють необхідність врахування в діяльності університету особливостей сучасного періоду, що пов'язані з його виживанням в досить жорсткій конкурентній боротьбі. Організація освітньої та наукової діяльності вимагає все більше елементів підприємництва в класичному розумінні цього слова, яке передбачає наступні основні моменти: 1) формування комплексу освітніх послуг, який в повній мірі буде відповідати потребам ринку; 2) активна позиція на ринку освітніх послуг та наукових досліджень, створення відповідних механізмів просування освітнього та наукового продукту; 3) розробка оптимального співвідношення «ціна-якість» освітніх послуг та інтелектуального продукту тощо.

Специсріка діяльності університету полягає в тому, що його конкурентоспроможність може бути оцінена $з$ позиції декількох суб'єктів: абітурієнтів (та їх батьків), державних замовників (Міністерства освіти та науки або іншого 
міністерства, що має мережу закладів вищої освіти), роботодавців у вигляді комерційних організацій та підприємств, державних і муніципальних установ, органів влади тощо. При цьому слід зазначити, що основою конкурентоспроможності університету є еорективне поєднання якісних і вартісних фракторів конкурентоспроможності. До складу якісних фракторів ми відносимо відмінні риси освітніх послуг університету, наукової діяльності профресорськовикладацького складу та компетенцій випускників, що пов'язані, серед іншого, зі здатністю університету гнучко та швидко реагувати на виклики навколишнього середовища (економічні, соціальні, політичні, екологічні, технологічні, юридичні та інші зміни). До вартісних фракторів належать, в першу чергу, витрати університету при здійсненні основної діяльності та ціна на освітні та науково-дослідні послуги, що надаються університетом.

За таких умов доцільно сорормулювати комплексний підхід до формування конкурентоспроможності університету. Він включає в себе наступні напрямки: вдосконалення системи базових відносин університету з внутрішнім та зовнішнім середовищем, використання сучасних принципів і вдосконалення методів управління конкурентоспроможністю університету, впровадження моделі фрормування конкурентоспроможності університету на ринку освітніх послуг.

Під базовими відносинами розуміємо сукупність елементів, організаційних структур, процесів, що визначають основні механізми діяльності університету. До них відносимо взаємини університету 3 профресорсько-викладацьким складом, студентами, замовниками наукових розробок, базовими галузями, органами влади та місцевою громадою. Дослідження університету через систему таких відносин дозволяє визначити цілі, завдання та способи їх побудови з перерахованими суб'єктами, визначити логіку інноваційного розвитку, критерії його результативності.

Важливим елементом організаційного забезпечення фрормування конкурентоспроможності університету $€$ принципи управління - обумовлені соціально-економічними особливостями надання освітніх послуг основні ідеї, що лежать в основі організації та діяльності університету, що самостійно здійснює управління своєю конкурентоспроможністю в ринковому середовищі. За результатами проведеного дослідження пропонуємо використовувати в діяльності університету наступні принципи.
1. Проактивна адаптація університету до змін зовнішнього середовища, в першу чергу, до зміни потреб економіки на локальному та глобальному рівнях та потреб населення.

2. Чесна конкуренція на ринку освітніх послуг з метою забезпечення законності процесу надання якісних послуг в інтересах усіх суб'єктів ринку.

3. Застосування системного підходу в реалізації всіх фрункцій університету як основи еорективного управління.

Управління конкурентоспроможністю університету - це управління в ринкових умовах своїми конкурентними перевагами, результатом якого $€$ покращення позиції по відношенню до конкурентів і стабільність діяльності університету, його ефективний розвиток.

Підвищення конкурентоспроможності університету $€$ завданням, яке не досягається випадковим чином, необхідна обґрунтована система забезпечення конкурентоспроможності. В основу управління конкурентоспроможністю університету має бути покладено стратегічний підхід, який реалізується через механізм управління. Організаційно-економічний механізм управління представляє собою систему досягнення цілей управління конкурентоспроможністю, що забезпечують необхідний кінцевий результат. Створення і вдосконалення подібного механізму шляхом адаптації до умов університетської екосистеми $€$ інструментом досягнення бажаного результату діяльності.

Механізм управління конкурентоспроможністю університету можна визначити як сукупність ресурсів, методів, засобів, інструментів і важелів впливу на внутрішні та зовнішні процеси, що застосовуються керівними структурами університету для досягнення цілей його розвитку. Механізм управління конкурентоспроможністю університету включає в себе наступні структурні елементи: цілі управління (бажаний результат діяльності, який має бути досягнутим в межах певного інтервалу часу); фрактори управління (фактори конкурентоспроможності, на які здійснюється вплив в інтересах досягнення поставлених цілей); організаційна структура управління; ресурси управління (матеріально-технічні, фрінансові, соціальні, інституційні та інші, при використанні яких реалізується обраний метод управління та забезпечується досягнення поставленої мети); методи впливу на фрактори (напрями, інструменти).

Елементи механізму управління конкурентоспроможністю університету на ринку освіт- 
ніх послуг представлені на рис. 1. Цілями управління у запропонованому механізмі виступає оперативна, тактична і стратегічна конкурентоспроможність, а також підвищення рівня конкурентоспроможності університету. Формування механізму управління конкурентоспроможністю має спиратися на сукупність принципів системності, цільової спрямованості, урахування специсріки діяльності, інфрормаційного забезпечення, використання сучасних технологій та інструментів, комплексної оцінки фракторів. Особливе значення в процесі управління конкурентоспроможністю мають принципи інноваційності, корпоративності, креативності, інтегрованості.

В основу системи управління конкурентоспроможністю університету через організаційно-економічний механізм покладено управління фракторами конкурентоспроможності. Впливаючи на фрактори конкурентоспроможності, університет може управляти рівнем своєї конкурентоспроможності, покращуючи при цьому конкурентні позиції на ринку освітніх послуг. Фактор конкурентоспроможності безпосередня причина, наявність якої $€$ необхідною та достатньою для зміни одного або декількох критеріїв конкурентоспроможності.

Найбільш важливою 3 точки зору системного підходу $є$ можливість поділу фракторів в залежності від джерел походження на внутрішні та зовнішні. Зовнішні фрактори - це соціально-економічні та організаційні відносини, що дозволяють університету створювати послуги, більш привабливі для стейкхолдерів. Зовнішні чинники відбивають умови, до яких університет повинен адаптуватися. Зовнішні чинники доцільно дисеренціювати залежно від характеру та інтенсивності впливу на мегарівень, макрорівень, мезорівень та мікрорівень. Внутрішні чинники - це можливості саме університету щодо забезпечення власної конкурентоспроможності, вони визначають ефективність процесу реагування на виклики, загрози, можливості зовнішнього середовища.

Особливу увагу слід приділити внутрішнім чинникам і зовнішнім фракторам мікрорівня, оскільки на них керівництво університету може безпосередньо впливати. Базовим i пріоритетним внутрішнім чинником конкурентоспроможності університету $€$ конкурентоспроможність його послуг. Крім того, відсутність можливості безпосередньо впливати на зовнішні чинники не означає, що керівництво університету може їх ігнорувати, необхідно здійснювати постійний моніторинг відповідних фракторів, прогнозувати їх зміну та наслідки цих змін для університету.

Для реалізації поставлених цілей підвищення рівня конкурентоспроможності необхідна сукупність ресурсів. Сукупність організаційних, фрінансово-економічних, людських, інформаційних, технологічних та інших ресурсів університету становить його конкурентоспроможний потенціал. Ресурси університету, як правило, обмежені в рамках конкретного просторово-часового інтервалу, що вимагає їх оптимального використання. Ресурсне обмеження має бути усвідомленим на ранніх етапах та може привести до перегляду раніше встановлених цілей та вибору методів впливу.

Важливою складовою механізму управління конкурентоспроможністю університету $€$ методи впливу. Найбільш ефективним методом управління конкурентоспроможністю $€$ методи стратегічного управління, контролю і самоорганізації, які дозволяють ефективно організувати діяльність, пов'язану з вирішенням поставленого завдання щодо підвищення рівня конкурентоспроможності університету на ринку освітніх послуг.

Розробка методів управління представляє собою визначення напрямів впливу та пошук, вибір (відбір, набір) найбільш дієвих засобів впливу (інструментів) (рис. 2). За допомогою методів та інструментів університет має можливість відстежувати зміни в зовнішньому середовищі, вносити своєчасні корективи в процес управління конкурентоспроможністю, здійснювати контроль і проводити організаційні зміни.

Організаційно-економічний механізм управління конкурентоспроможністю університету ефективно реалізується в технології управління. Пропонуємо використання процесного підходу, який дозволяє розглядати технологію як комплекс організаційних заходів, операцій і прийомів, спрямованих на підвищення конкурентоспроможності університету на ринку освітніх послуг на основі визначення зон прямого та опосередкованого впливу на цінність/конкурентоспроможність освітньої пропозиції. Процес управління представляє собою систему безперервних взаємопов'язаних дій зі стратегічного маркетингу, планування, адміністрування, обліку і контролю, мотивації, регулювання, та складається з наступних етапів:

1. Стратегічний аналіз ситуації на ринку освітніх послуг.

2. Комплексний аналіз конкурентоспроможності університету за визначеною системою індикаторів. 


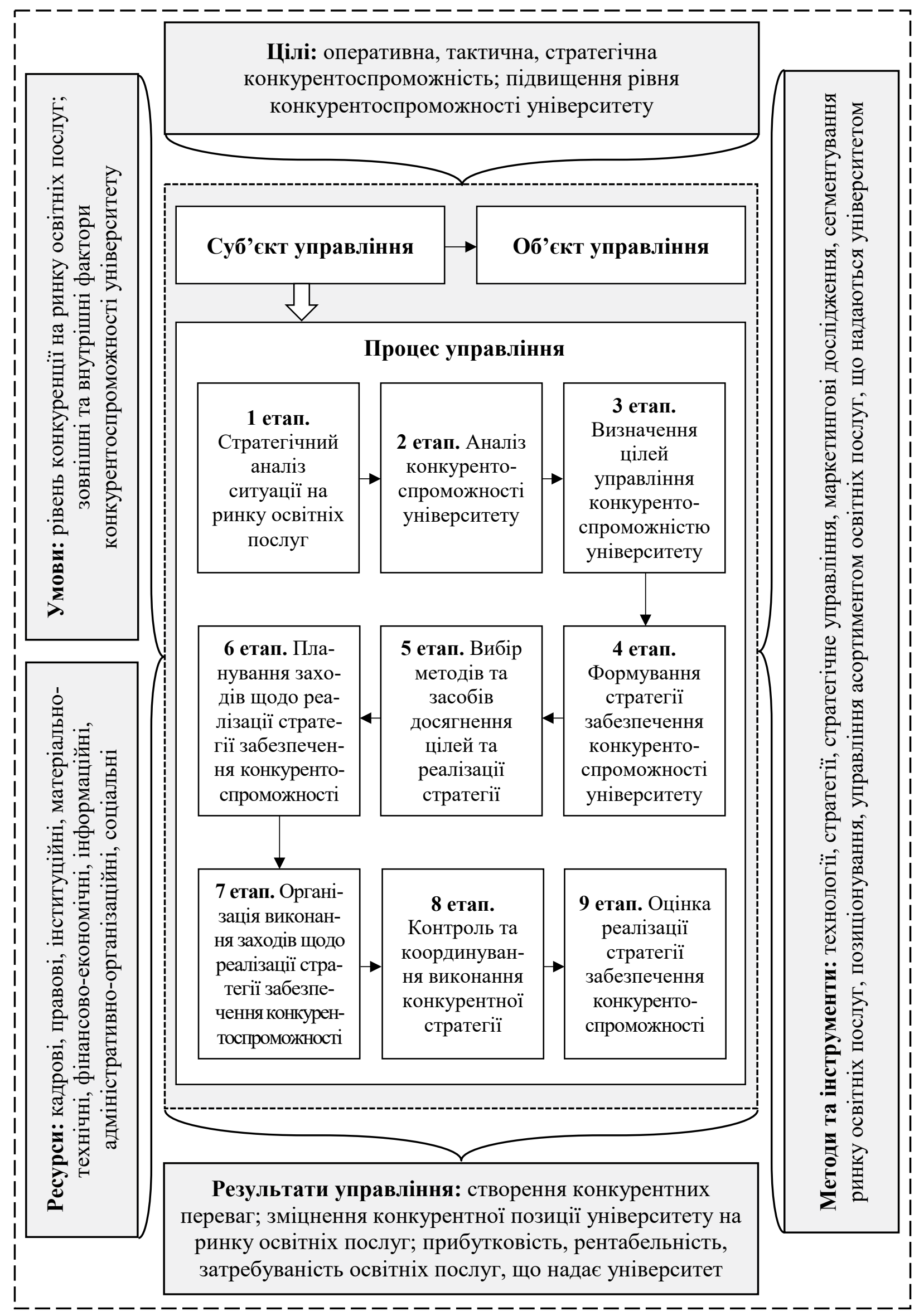

Рис. 1. Механізм управління конкурентоспроможністю університету на ринку освітніх послуг 


\section{ІНСТРУМЕНТИ УПРАВЛІННЯ КОНКУРЕНТОСПРОМОЖНІСТЮ УНІВЕРСИТЕТУ}

\begin{tabular}{|c|c|}
\hline $\begin{array}{l}\text { Нормативно- } \\
\text { правові }\end{array}$ & $\begin{array}{l}\text { Система законодавчих норм та правил визначає права і } \\
\text { форми власності, умови укладення договорів } \\
\text { контрагентами та споживачами послуг, порядок } \\
\text { реєстрації та функціонування університету }\end{array}$ \\
\hline $\begin{array}{l}\text { Адміністра- } \\
\text { тивні (прямі) }\end{array}$ & $\begin{array}{l}\text { Зводяться до прямого адміністративного впливу на } \\
\text { діяльність університету }\end{array}$ \\
\hline $\begin{array}{l}\text { Економічні } \\
\text { (непрямі) }\end{array}$ & $\begin{array}{l}\text { Безпосередньо впливають на кон'юнктуру ринку (попит } \\
\text { і пропозиція) та через неї опосередковано на надавачів і } \\
\text { споживачів освітніх послуг }\end{array}$ \\
\hline Інтеграційні & $\begin{array}{l}\text { Використання ефекту конкурентно-колабораційних } \\
\text { відносин в межах єдиного освітньо-наукового простору } \\
\text { в регіоні та/або галузі, що призведе до зростання якості } \\
\text { освіти та наукових досліджень }\end{array}$ \\
\hline Соціальні & $\begin{array}{l}\text { Вплив соціокультурного середовища та професійних й } \\
\text { особистісних характеристик учасників освітнього } \\
\text { процесу на сприйняття індикаторів конкуренто- } \\
\text { спроможності; регулювання напряму та інтенсивності } \\
\text { цього впливу та узгодження спільних підходів }\end{array}$ \\
\hline $\begin{array}{c}\text { Інструменти } \\
\text { індикативного } \\
\text { планування }\end{array}$ & $\begin{array}{l}\text { Багатоетапний процес, що включає в себе розробку } \\
\text { стратегічного плану розвитку (гнучкий характер змісту } \\
\text { та інструментів, контекстне та ситуативне коригування) }\end{array}$ \\
\hline $\begin{array}{c}\text { Інструменти } \\
\text { зовнішнього } \\
\text { програмування }\end{array}$ & $\begin{array}{l}\text { Основний інструмент прямого активного втручання } \\
\text { держави в хід освітнього процесу в умовах ринкових } \\
\text { відносин; стандартизація вимог до якості освітньої } \\
\text { діяльності та результатів навчання }\end{array}$ \\
\hline $\begin{array}{l}\text { Релевантні } \\
\text { управлінські } \\
\text { інструменти }\end{array}$ & $\begin{array}{l}\text { Використання потенціалу висококваліфікованих кадрів, } \\
\text { що володіють інноваційним мисленням; формування } \\
\text { атмосфери довіри для спільного креативного процесу } \\
\text { саморозвитку }\end{array}$ \\
\hline Моніторинг & $\begin{array}{l}\text { Дозволяє своєчасно отримати результати діяльності } \\
\text { університету для їх подальшого аналізу та оцінки }\end{array}$ \\
\hline
\end{tabular}

Рис. 2. Інструменти управління конкурентоспроможністю університету 
3. Визначення цілей управління конкурентоспроможністю університету.

4. Формування стратегії забезпечення конкурентоспроможності університету та забезпечення ії̈ реалізації на основі процесного підходу.

5. Вибір методів та засобів досягнення цілей та реалізації стратегії.

6. Планування та організація виконання заходів щодо реалізації стратегії забезпечення конкурентоспроможності.

7. Контроль та координування етапів, процесів, результатів конкурентної стратегії.

8. Оцінка реалізації стратегії забезпечення конкурентоспроможності.

Таким чином, запропонований механізм дозволяє на основі використання різних методів та інструментів сорормувати тривалі та стійкі конкурентні переваги, результатом чого буде покращення конкурентної позиції університету на ринку освітніх послуг.

Використання механізму дозволяє визначити рівень конкуренції на ринку освітніх послуг, провести аналіз впливу внутрішніх та зовнішніх чинників на рівень конкурентоспроможності університету, виявити основні напрямки підвищення рівня його конкурентоспроможності, оцінити есрективність запропонованих заходів.

Висновки. Досягнення високого рівня конкурентоспроможності університету є найважливішою стратегічною перевагою. Управління конкурентоспроможністю університету вимагає профресійних знань та часу, певних коштів і ресурсів, ринкового відповідального інноваційного мислення керівників і фрахівців. Управління конкурентоспроможністю уні- верситету має поєднувати короткостроковий аспект (тактичне управління) і довгострокові цілі (стратегічне управління). Важливим $€$ усвідомлення значущості системного характеру комплексу процесів: фрормування, реалізації, вдосконалення механізму управління конкурентоспроможністю університету на ринку освітніх послуг на основі концентрації уваги на ідентисрікації, забезпеченні та зміцненні його конкурентних переваг.

Комплексний підхід до управління конкурентоспроможністю університету в ринковому середовищі сприятиме розробці конкурентної стратегії його розвитку, що включатиме в себе освітньо-підприємницьку, науково-підприємницьку та виховну діяльність, що відповідає загальнометодологічним принципам управління та принципам фрормування і підтримки конкурентоспроможності університету. Обов'язковими елементами даної стратегії $€$ теоретично обґрунтовані концептуальні ідеї (принципи, моделі, підходи тощо) та механізми їх практичної реалізації.

Складність університету як об'єкту дослідження і висока мінливість зовнішнього середовища вимагають постійного моніторингу розвитку практичних методів і наукових концепцій економіки та управління освітою. Моніторинг має охоплювати численні аспекти фрункціонування університету на місцевому, регіональному та національному рівні, профільних міжнародних ринках, включати в ссреру аналізу всі елементи даної складної системи. Подібні дослідження вносять значний вклад у вирішення сучасних проблем сорери освіти і закладають науково-методологічну основу для перспективного планування і управління.

\section{СПИСОК ВИКОРИСТАНИХ ДЖЕРЕЛ:}

1. Антонюк Л.Л., Ільницький Д.О., Барабась Д.О., Сандул М С. Міжнародна конкурентна диспозиція національних систем вищої освіти. Міжнародна економічна політика. 2017. № 2(27). С. 7-32.

2. Каленюк І.С. Напрями трансформації механізмів фрінансування освіти в сучасному світі. Демографрія та соціальна економіка. 2017. № 1(29). С. 24-36.

3. Levchenko O., Kryvorotenko A. Theoretical Approaches to Determine the Essence of Transfer of Educational Knowledge in the System of Higher Education. Central Ukrainian Scientific Bulletin. Economic Sciences. 2019. № 2(35). P. 32-40.

4. Нагорняк Т.Л. Розвиток потенціалу закладу вищої освіти в системі управлінських практик. Економіка $i$ організація управління. 2020. № 4(40). С. 186-196.

5. Shaulska L., Laktionova O., Nagornyak T., Sereda H. Performance management at Ukrainian university: A case of the KPIs use. Problems and Perspectives in Management. 2021. № 19(1). P. 78-89.

6. Shaulska L., Yurchyshena L., Popovskyi Yu. Using MS Power BI Tools in the University Management System to Deepen the Value Proposition. 11th International Conference on Advanced Computer Information Technologies (ACIT). 2021. P. 294-299. 


\section{REFERENCES:}

1. Antoniuk L.L., Inytskyi D.O., Barabas D.O. and Sandul M.S. (2017) Mizhnarodna konkurentna dyspozytsiia natsionalnykh system vyshchoi osvity [International competitive disposition of national higher education systems]. Mizhnarodna ekonomichna polityka, vol. 2(27), pp. 7-32. (in Ukrainian)

2. Kaleniuk I.S. (2017) Napriamy transformatsii mekhanizmiv finansuvannia osvity v suchasnomu sviti [Directions of transformation of mechanisms of financing of education in the modern world]. Demohrafiia ta sotsialna ekonomika, vol. 1(29), pp. 24-36. (in Ukrainian)

3. Levchenko O. and Kryvorotenko A. (2019) Theoretical Approaches to Determine the Essence of Transfer of Educational Knowledge in the System of Higher Education. Central Ukrainian Scientific Bulletin. Economic Sciences, vol. 2(35), pp. 32-40. (in Ukrainian)

4. Nahorniak T.L. (2020) Rozvytok potentsialu zakladu vyshchoi osvity $v$ systemi upravlinskykh praktyk [Development of the potential of a higher education institution in the system of management practices]. Ekonomika i orhanizatsiia upravlinnia, vol. 4(40), pp. 186-196. (in Ukrainian)

5. Shaulska L., Laktionova O., Nagornyak T. and Sereda, H. (2021) Performance management at Ukrainian university: A case of the KPI's use. Problems and Perspectives in Management, vol. 19(1), pp. 78-89.

6. Shaulska L., Yurchyshena L. and Popovskyi Yu. (2021) Using MS Power BI Tools in the University Management System to Deepen the Value Proposition. 11th International Conference on Advanced Computer Information Technologies (ACIT), pp. 294-299. 